\title{
Hambatan pendidikan inklusi dan bagaimana mengatasinya: Telaah kritis sistematis dari berbagai negara
}

\begin{tabular}{l} 
Citra Nadia Sari ${ }^{\text {I* }}$, Wiwin \\
I,2Fakultas Psikologi, Univers \\
\hline Info Artikel \\
\hline Sejarah Artikel: \\
Diterima \\
04 November 2020 \\
Direview \\
04 November 2020 \\
Disetujui \\
05 Januari 2021 \\
Dipublikasikan \\
I5 Januari 202I \\
\hline Keywords: \\
Barriers, \\
challenges, \\
inclusive education, \\
optimizing, \\
strategy.
\end{tabular}

\begin{abstract}
Abstrak
Objektif: Artikel ini bertujuan untuk mengulas tantangan dan hambatan yang dihadapi pelaksanaan pendidikan inklusi serta strategi yang dapat dilakukan oleh negara.

Metode: Artikel ini merupakan telaah kritis sistematis . Jurnal diambil dari 9 situs artikel penelitian internasional berbeda. Pencarian jurnal diutamakan terbit tahun 20 I I-2020. Didapatkan I I jurnal yang merupakan jurnal kualitatif. Temuan: Hambatan yang dihadapi yaitu tenaga pendidik kurang terlatih, stigma negatif, kebijakan otoritas yang kurang aplikatif, kurangnya pengetahuan tenaga pendidik, hambatan aksesibilitas, keterbatasan sumber belajar, dan keterbatasan finansial. Strategi yang dilakukan yaitu peningkatan kualitas inservice training (INSET), awareness programmes, school-based professional development programmes, family support, kontekstualisasi proses belajarmengajar, dukungan berkelanjutan selama proses implementasi di lapangan, komitmen pemerintah memberikan sebagian prosentase dari GNP sebagai sumber dana, kolaborasi dengan stakeholders, dan kerjasama regional, nasional, maupun internasional.
\end{abstract}

Kesimpulan: Ada beberapa strategi yang dapat dilakukan di Indonesia, yaitu pelatihan kepada guru kelas, menyelenggarakan awareness program, bekerjasama dengan tim Pokja yang memiliki resource center yang mendukung implementasi pendidikan inklusi, penyediaan dana untuk menyelenggarakan pelatihan guru kelas, dan membangun fasilitas umum yang lebih ramah terhadap individu dengan disabilitas.

\section{Barriers to inclusive education and how to solve them: $A$ systematic critical review from different countries}

Objectives:. This article aims to review the challenges, barriers faced, and strategies Inclusive education can be done by the state.

Method: This is a systematic critical review. Journals taken from 9 different international research article sites. The search for journals mainly published in $201 \mathrm{I}$ 2020. Initial search collected 31 journals and filtered using inclusion criteria. There were II journals consisting of I I qualitative journals.

Findings: The barriers are poorly trained educators, negative stigma, inadequate authority policies, lack of knowledge of educators, accessibility constraints, limited learning resources, and financial limitations. The strategies are improve the quality of in-service training (INSET), awareness programs, school-based professional development programs, family support, contextualization of teaching-learning process, continued support during implementation process in the field, government's commitment to provide a portion of the GNP as a resource funds, collaboration with stakeholders, and regional, national and international cooperation.

Conclusions: There are several strategies that can be implemented in Indonesia, there are classroom teacher training, holding awareness programs, collaborating with a Pokja team that has a resource center that supports the implementation of inclusive education, providing funds to conduct classroom teacher training, and building public facilities that are more friendly to individuals with disabilities.

*Alamat korespondensi:

[Jl. Airlangga No. 4-6, Airlangga, Gubeng, Surabaya, Jawa Timur, Indonesia 60286]

[citra.nadia.sari-2019@psikologi.unair.ac.id] 


\section{Pendahuluan}

Pendekatan dalam memandang individu dengan disabilitas telah terjadi pergeseran pandangan menjadi model sosial selama tiga dekade terakhir (Oliver, 20I 3 dalam Genova, 20I5). Pergeseran ini terjadi disebabkan adanya regulasi dan peraturan mengenai individu dengan disabilitas dengan diberlakukannya The United Nations (UN) "Convention on the Rights of Persons with Disabilities" (CRPD) oleh Perserikatan Bangsa-Bangsa (United Nations) (United Nations, 2006). Pendidikan inklusi menjadi fokus kebijakan pendidikan tingkat internasional yang menjamin kesetaraan pendidikan bagi anak tanpa maupun dengan disabilitas. Sebelum diberlakukan kebijakan ini, sudah ada beberapa kali deklarasi dan kebijakan mengenai individu dengan disabilitas. Seperti di Eropa, ada kebijakan "Law on Special Educations" tahun 1998 yang memastikan bahwa anak dengan kebutuhan khusus memiliki hak untuk terintegrasi secara penuh atau sebagian di sekolah yang dekat dengan tempat tinggalnya yang memiliki program pendidikan khusus (Genova, 2015). Tak hanya itu, UNESCO telah mengeluarkan Deklarasi Salamanca yang ditandatangani oleh 92 negara yang mempromosikan pendidikan inklusi untuk melawan diskriminasi terhadap siswa dengan hambatan dalam pembelajaran dan perkembangan dan untuk menciptakan komunitas yang lebih terbuka terhadap semua individu, dengan atau tanpa disabilitas (UNESCO, 1994). Tidak hanya itu saja, kebijakan "Education For All" (EFA) dikeluarkan untuk menjamin semua anak dapat memperoleh pendidikan terlepas dari latar belakang maupun memiliki disabilitas atau tidak (Centre for Services and Information on Disability (CSID), 2002).

Kebijakan yang muncul setelah adanya deklarasi juga tidak terhitung jumlahnya. Di Bangladesh, pemerintah telah mengeluarkan tiga kebijakan tentang kesetaraan pendidikan untuk semua siswa, dengan atau tanpa disabilitas, yaitu Education Policy 2000, Education Policy 2010, dan Persons with Disability Welfare Act 200 I (Kawser et al., 2016). Di Eropa, ada kebijakan European Disability Strategy 2010-2020 yang bertujuan untuk pemberdayaan dan partisipasi penuh individu dengan disabilitas dalam masyarakat, sebagai implementasi dari CRPD (EC (European Commission), 20 I0). Ada kebijakan "Education White Paper" sebagai kebijakan pendidikan inklusi pertama di Afrika Selatan yang bertujuan untuk memberikan kesetaraan pendidikan untuk semua anak (Department of Education, 200 I). Di India, ada kebijakan "Sarva Siksha Abhiyan" yang bertujuan untuk memberikan kesempatan pendidikan pada individu dengan disabilitas untuk bersekolah di dalam setting pendidikan regular (Education for All Movement, 200I). Ada kebijakan The Pacific Education Development Framework (PEDF) yang dikeluarkan oleh Kementerian Kepulauan Pasifik untuk menjamin kebutuhan pendidikan siswa dengan disabilitas sebagai prioritas pendidikan (PIFS (Pacific Islands Forum Secretariat), 2009).

Kebijakan dan deklarasi yang telah dikeluarkan tersebut memperkuat dasar hukum diselenggarakannya pendidikan inklusi bagi negara-negara yang berada di bawah naungan PBB dan negara-negara yang juga ikut menandatangani Deklarasi Salamanca. Namun pada kenyataannya, ada banyak sekali hambatan dan tantangan yang dialami selama penyelenggaraan sekolah inklusi. Bangladesh mengalami sedikit kemajuan dalam menyediakan pendidikan untuk disabilitas di sekolah regular, terlepas dari sudah ada tiga kebijakan mengenai pendidikan untuk anak dengan disabilitas (UNESCO, 2010 dalam Kawser et al., 20 I6). Individu dengan disabilitas yang terlahir di Kepulauan Pasifik memiliki kesempatan yang sangat kecil untuk menghadiri sekolah. Kurang dari sepuluh siswa dengan disabilitas yang beruntung bisa mendapatkan pendidikan (Pacific Islands Forum Secretariat, 2009).

Pada praktek di lapangan, ada beberapa sekolah yang tidak ingin menerima siswa dengan disabilitas (Bhatnagar \& Das, 20 I4; Kawser et al., 20 I6). Ada juga beberapa anak dengan disabilitas tidak ingin menghadiri sekolah karena merasa rendah diri akan ketidakmampuannya (Sharma et al., 20l7) dan tidak merasa yakin dengan kemampuan yang dimiliki, walaupun memiliki harapan dan cita-cita ingin menjalani profesi seperti apa (Genova, 20I5). Begitu pula dengan siswa dengan disabilitas yang menghadiri sekolah. Mereka merasa tidak ingin melanjutkan sekolah karena adanya sikap dan stigma negatif yang diberikan oleh teman-temannya dan guru-gurunya (Genova, 20 I5). Hal ini yang menyebabkan tingkat anak dengan putus sekolah menjadi tinggi di Negara Yunani, Spanyol, dan Lithuania (Genova, 20I5). Anak dengan disabilitas lebih banyak tidak melanjutkan sekolah (Abongdia et al., 20I5), dan orangtua juga tidak menyekolahkan anak karena takut dengan stigma 
yang diberikan oleh lingkungan sekitar anak (Kawser et al., 2016). Bahkan sikap negatif ini berdampak pada pembiaran anak dengan disabilitas hanya duduk diam di kelas tanpa pemberian instruksi oleh guru (Jia \& Santi, 2020).

Realitas yang terjadi di lapangan masih jauh dari kondisi ideal yang tercantum dalam kebijakan dan deklarasi yang sudah disepakati oleh banyak negara. Banyak pertanyaan yang muncul tentang mengapa praktek pendidikan inklusi di lapangan menjadi begitu sulit diterapkan, walaupun kebijakan dan deklarasi telah tertulis dan disepakati oleh banyak negara. Sebenarnya apa saja yang dihadapi oleh beberapa negara sehingga mengalami kesulitan untuk menyelenggarakan sekolah inklusi yang ramah terhadap anak dengan disabilitas. Pertanyaan-pertanyaan inilah yang akan dibahas dan diulas dalam artikel telaah kritis sistematis ini sehingga gambaran besar tentang tantangan dan hambatan yang dialami oleh negara-negara yang menyelenggarakan pendidikan inklusi dapat terjawab serta bagaimana strategi yang dilakukan oleh berbagai negara untuk menyelesaikan permasalahan yang dihadapi selama menyelenggarakan pendidikan inklusi. Gambaran besar tentang permasalahan yang dialami dan strategi untuk mengatasinya oleh beberapa negara tersebut dapat dijadikan sebagai pertimbangan dan aspek-aspek apa saja yang harus diperhatikan untuk dapat menyelenggarakan pendidikan inklusi dengan baik dan sesuai dengan kondisi ideal yang seharusnya.

\section{Metode}

Artikel ini merupakan artikel kajian telaah kritis sistematis. Pencarian artikel ilmiah dilakukan melalui 9 situs jurnal internasional, yaitu ScienceDirect (sciencedirect.com), SAGE (journals.sagepub.com), ProQuest (media.proquest.com), Wiley Online Library (onlinelibrary.wiley.com), ERIC (eric.ed.gov), Taylor and Francis (tandfonline.com), Springer (springer.com), ResearchGate (researchgate.net) dan Google Scholar (scholar.google.com). Penentuan artikel ilmiah dilakukan melalui 9 situs jurnal internasional karena artikel-artikel pada situs tersebut sudah menyebutkan konteks penelitian dengan jelas. Pencarian artikel ilmiah dilakukan pada tanggal 27 Maret 2020 - 28 Maret 2020. Kata kunci yang digunakan yaitu "challenges to inclusive to education" DAN "barriers to inclusive education" DAN "optimalizing inclusive education", dengan jangkauan tahun publikasi I 0 tahun terakhir (20 I I -2020). Analisis data artikel kajian telaah kritis sistematis menggunakan panduan PRISMA-P 2015 (Moher et al., 2016).

Pemilihan jurnal ilmiah dilakukan berdasarkan beberapa prinsip kriteria inklusi, yaitu: I) artikel penelitian ilmiah mengenai tantangan yang dihadapi sekolah inklusi, 2) artikel penelitian ilmiah mengenai hambatan yang dihadapi sekolah inklusi, 3) artikel penelitian ilmiah mengenai strategi untuk mengoptimalkan pendidikan inklusi, 4) penelitian empiris (kualitatif dan kuantitatif), 5) jurnal ilmiah berbahasa inggris, 6) artikel dapat diakses oleh umum (open access article), dan 7) artikel lengkap dapat diunduh.

Pencarian artikel ilmiah menghasilkan I I dari 3 I jurnal artikel penelitian ilmiah yang akan direview, diantaranya 7 jurnal dari Taylor and Francis, I dari Google Scholar, I dari jurnal ERIC, I dari ResearchGate, dan I dari jurnal Wiley Online Library. Tidak ada jurnal penelitian ilmiah yang relevan yang ditemukan di SAGE, ScienceDirect, ProQuest, dan Springer.

\section{Hasil}

Hasil pencarian artikel ilmiah memberikan berbagai macam pemahaman mengenai penyelenggaraan pendidikan inklusi di berbagai negara. Uniknya, setiap negara memiliki tantangan yang berbedabeda yang dipengaruhi oleh budaya, lingkungan sekitar, pemangku kebijakan, dan karakter khas individu dari berbagai negara. Strategi yang ditawarkan oleh berbagai negara untuk menyelesaikan tantangan dan hambatan yang dialami juga bervariasi, dan hal tersebut sekali lagi disesuaikan dengan karakter khas masing-masing negara. Di bawah ini merupakan daftar hasil pencarian artikel ilmiah yang telah disaring menggunakan kriteria inklusi. 
Tabel I

Daftar jurnal ilmiah yang dianalisis

\begin{tabular}{|c|c|c|c|c|c|c|}
\hline No & Penulis & Tahun & Judul & Lokasi & Metode & Sumber \\
\hline $\mathrm{I}$. & $\begin{array}{l}\text { Umesh Sharma, } \\
\text { Ann Cheryl } \\
\text { Armstrong, } \\
\text { Laisiasa } \\
\text { Merumeru, } \\
\text { Janine Simi \& } \\
\text { Hannah Yared }\end{array}$ & 2018 & $\begin{array}{l}\text { Addressing barriers to } \\
\text { implementing inclusive } \\
\text { education in the Pacific }\end{array}$ & Kep. Pasifik & Quali & tandfonline.com \\
\hline 2. & $\begin{array}{l}\text { Umme Kawser, } \\
\text { Maliha Ahmed, } \\
\text { Mostak Ahmed }\end{array}$ & 2016 & $\begin{array}{l}\text { Barriers of Inclusive } \\
\text { Education in } \\
\text { Bangladesh: Making } \\
\text { Inclusion a Reality }\end{array}$ & Bangladesh & Quali & researchgate.net \\
\hline 3. & Angela Genova & 2015 & $\begin{array}{l}\text { Barriers to inclusive } \\
\text { education in Greece, } \\
\text { Spain and Lithuania }\end{array}$ & $\begin{array}{l}\text { Greece, } \\
\text { Spain, and } \\
\text { Lithuania }\end{array}$ & Quali & tandfonline.com \\
\hline 4. & $\begin{array}{l}\text { Jane-Francis } \\
\text { Afungmeyu } \\
\text { Abongdia, John } \\
\text { Wankah Foncha } \\
\text { \& Alinda Dakada }\end{array}$ & 2017 & $\begin{array}{l}\text { Challenges Encountered } \\
\text { by Teachers in } \\
\text { Identifying Learners with } \\
\text { Learning Barriers: } \\
\text { Toward Inclusive } \\
\text { Education }\end{array}$ & South Africa & Quali & tandfonline.com \\
\hline 5. & $\begin{array}{l}\text { M. Tariq Ahsan, } \\
\text { Umesh Sharma } \\
\text { and Joanne M. } \\
\text { Deppeler }\end{array}$ & 2012 & $\begin{array}{l}\text { Challenges to prepare } \\
\text { pre-service teachers for } \\
\text { inclusive education in } \\
\text { Bangladesh: beliefs of } \\
\text { higher educational } \\
\text { institutional heads }\end{array}$ & Bangladesh & Quali & tandfonline.com \\
\hline 6. & L Jia, M Santi & 2020 & $\begin{array}{l}\text { Chinese regular } \\
\text { classroom teachers' } \\
\text { understanding } \\
\text { of barriers to inclusive } \\
\text { education }\end{array}$ & $\begin{array}{l}\text { Shuangliu } \\
\text { District, } \\
\text { Sichuan } \\
\text { Province, } \\
\text { China }\end{array}$ & Quali & $\begin{array}{c}\text { ojs.pensamultime } \\
\text { dia.it }\end{array}$ \\
\hline 7. & $\begin{array}{l}\text { Lucia Potgieter- } \\
\text { Groot, Maretha } \\
\text { Visser, and } \\
\text { Carien Lubbe- } \\
\text { de Beer }\end{array}$ & 2012 & $\begin{array}{l}\text { Emotional and } \\
\text { behavioural barriers to } \\
\text { learning and } \\
\text { development in the } \\
\text { inclusive education } \\
\text { classrooms in South } \\
\text { Africa: Developing a } \\
\text { training programme for } \\
\text { teachers }\end{array}$ & South Africa & Quali & tandfonline.com \\
\hline 8. & $\begin{array}{l}\text { Bhatnagar, } \\
\text { Nisha; Das, Ajay }\end{array}$ & 2014 & $\begin{array}{l}\text { Regular School } \\
\text { Teachers' Concerns and } \\
\text { Perceived Barriers to } \\
\text { Implement Inclusive } \\
\text { Education in New Delhi, } \\
\text { India }\end{array}$ & $\begin{array}{l}\text { New Delhi, } \\
\text { India }\end{array}$ & Quali & eric.ed.gov \\
\hline 9. & $\begin{array}{l}\text { Umesh Sharma, } \\
\text { Tim Loreman, } \\
\text { Janine Simi }\end{array}$ & 2017 & $\begin{array}{l}\text { Stakeholder perspectives } \\
\text { on barriers and } \\
\text { facilitators of inclusive } \\
\text { education in the } \\
\text { Solomon Islands }\end{array}$ & $\begin{array}{l}\text { Kep. } \\
\text { Solomon }\end{array}$ & Quali & $\begin{array}{l}\text { onlinelibrary.wiley } \\
\text {.com }\end{array}$ \\
\hline
\end{tabular}




\begin{tabular}{l|llll}
\hline Denise Beutel, & $\begin{array}{l}\text { Donna Tangen } \\
\text { \& Suzanne } \\
\text { Carrington }\end{array} 2018$ & $\begin{array}{l}\text { Building bridges between } \\
\text { global concepts and } \\
\text { local contexts: } \\
\text { implications for inclusive } \\
\text { education in Nepal, Sri } \\
\text { Lanka, and Bangladesh }\end{array}$ & Quali & tandfonline.com \\
\hline $\begin{array}{l}\text { Markéta } \\
\text { Bačáková and }\end{array}$ & $\begin{array}{l}\text { Continuing professional Czech } \\
\text { development (CPD) as a } \\
\text { means to reducing } \\
\text { barriers to inclusive } \\
\text { education }\end{array}$ & Republic & Quali & tandfonline.com \\
\hline
\end{tabular}

Melalui kriteria inklusi, ditemukan total II jurnal yang dianalisis menggunakan teknik analisis PRISMA-P 2015 (Moher et al., 20I6). Artikel ilmiah dengan tahun terbit 20I2-2020 (10 tahun terakhir), merupakan penelitian empiris (I I jurnal kualitatif), dan membahas tentang tantangan, hambatan, dan strategi untuk meminimalisir hambatan serta mengoptimalkan pendidikan inklusi. Di bawah ini merupakan tabel daftar hambatan dan tantangan yang dihadapi oleh berbagai negara dalam menyelenggarakan pendidikan inklusi yang diambil dari 9 jurnal ilmiah.

\section{Tabel II}

Tabel tantangan dan hambatan yang dialami oleh berbagai negara dalam menyelenggarakan Pendidikan Inklusi

\begin{tabular}{|c|c|c|c|c|c|c|c|c|c|c|c|c|c|c|c|c|}
\hline \multirow[t]{2}{*}{ No. } & \multicolumn{16}{|c|}{ Barriers } \\
\hline & 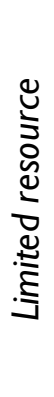 & 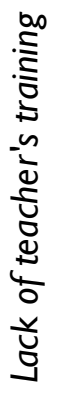 & 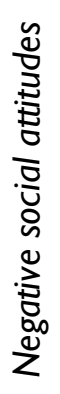 & 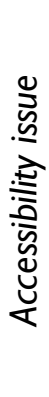 & 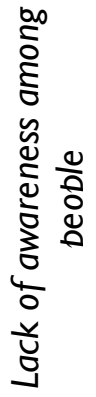 & 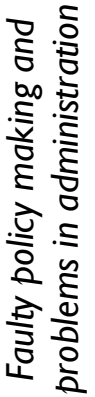 & 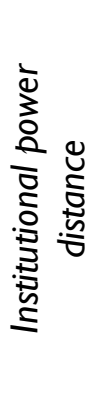 & 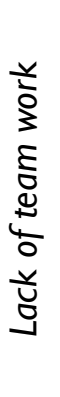 & 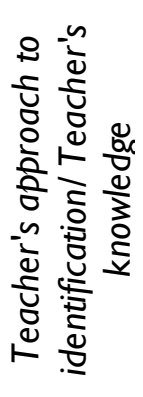 & 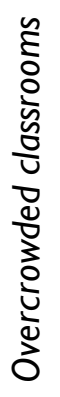 & 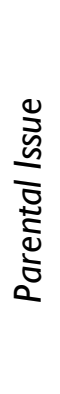 & 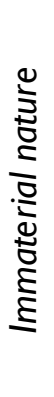 & 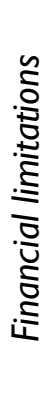 & 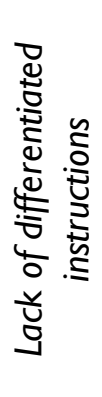 & 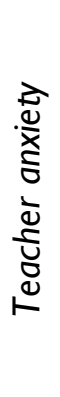 & 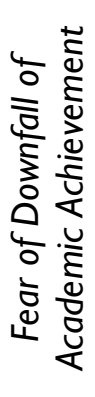 \\
\hline
\end{tabular}

\begin{tabular}{|c|c|c|c|c|c|c|c|c|c|c|c|c|c|c|c|}
\hline $\mathrm{I}$. & I & 1 & I & I & 1 & 1 & 1 & & I & & & 1 & I & & \\
\hline 2. & $T$ & $T$ & $T$ & $T$ & $T$ & $T$ & $T$ & 1 & & 1 & & & 1 & & \\
\hline 3. & & $T$ & $T$ & $T$ & 1 & 1 & 1 & & $T$ & & & 1 & 1 & & \\
\hline 4. & & 1 & & & & & & 1 & I & 1 & 1 & & & & \\
\hline 5. & I & 1 & 1 & 1 & & & & & 1 & $\mathrm{~T}$ & & & 1 & & \\
\hline 6. & & I & I & & & & & & I & I & 1 & & I & I & \\
\hline 7. & & $T$ & T & & 1 & & & & $T$ & & & & & & \\
\hline 8. & & I & I & 1 & & $T$ & 1 & & 1 & 1 & 1 & 1 & I & 1 & 1 \\
\hline 9. & I & 1 & 1 & 1 & & I & 1 & & & & & & & & \\
\hline Total & 4 & 9 & 8 & 6 & 4 & 5 & 5 & 2 & 7 & 5 & 2 & 3 & 6 & 2 & $T$ \\
\hline
\end{tabular}

Berdasarkan tabel tersebut, banyaknya tantangan dan hambatan yang dialami oleh beberapa negara jika diurutkan dari yang terbanyak yaitu: kurangnya pelatihan guru ( 9 penelitian), sikap negatif terhadap disabilitas (8 penelitian), pemahaman guru tentang disabilitas dan identifikasi disabilitas ( 7 penelitian), kurangnya pembedaan instruksi, hambatan dalam aksesibilitas (masing-masing 6 penelitian), kesalahan dalam pembuatan kebijakan, kebijakan institusional yang kurang memahami disabilitas, dan jumlah kelas yang besar (masing-masing 5 penelitian), kurangnya kesadaran masyarakat terhadap disabilitas, sumber daya yang terbatas (masing-masing 4 penelitian), keterbatasan financial ( 3 penelitian), kurangnya kerjasama antar guru dan antar elemen masyarakat, kecemasan guru, dan permasalahan pada keterlibatan orangtua dalam pendidikan anak dengan disabilitas (masing-masing 2 penelitian), kondisi alam yang kurang bersahabat, dan kekhawatiran akan prestasi siswa dengan disabilitas (masing-masing I penelitian). 


\section{Limited Resource}

Penelitian yang dilakukan di Pasifik menyatakan bahwa "...the three key themes evident as barriers to inclusion were ... a lack of adequate resources..." (Sharma et al., 2018). Selaras dengan penelitian tersebut, penelitian yang dilakukan di Kepulauan Solomon juga menyatakan bahwa "current schools also lack ... and other learning materials that will support children with disabilities in the education system" (Sharma et al., 2017). Penelitian di Bangladesh menyebutkan bahwa "In the mainstream schools these resources are not available to facilitate special need children and it makes the inclusion difficult and impossible" (Kawser et al., 2016).

\section{Lack of teacher's training}

Penelitian yang dilakukan di Pasifik menyatakan bahwa "Poor teacher education programmes, which subsequently leads to a lack of teacher capability and poor teaching pedagogies at the micro level, was also flagged as a barrier..." (Sharma et al., 20 I8). Senada dengan penelitian tersebut, penelitian di Kepulauan Solomon menyatakan bahwa "'...teachers need training to enable them to become inclusive teachers' dan 'untrained teachers will find it difficult to assist children with disabilities. This is especially with teachers in training" (Sharma et al., 20 I7). Penelitian di Bangladesh menyebutkan bahwa "There is lack of trained teacher in inclusive education system too. The mainstream school teachers do not have any proper training to handle special need children and most of the time they are not interested to take training by thinking it is an extra burden. Government takes projects but often does not put into service" (Kawser et al., 2016). Selaras dengan penelitian tersebut, penelitian yang juga dilakukan di Bangladesh menyatakan bahwa "... a lack of sufficient training for the teacher educators was also a challenge in implementing inclusive education" (Ahsan et al., 20I2). Penelitian di Yunani menyebutkan bahwa "'future teachers are not trained at university on how to deal with pupils with disability"' (Genova, 2015). Penelitian di Afrika Selatan menyatakan bahwa “...the kind of training provided for teachers was not effective in addressing their challenges with regard to the implementation of the inclusive policy..." (Abongdia et al., 20I5). Selaras dengan penelitian tersebut, penelitian lainnya yang juga dilakukan di Afrika Selatan menyatakan bahwa "... a need for training and support to deal with learners experiencing emotional and behavioural barriers, because they had no previous training to deal with the situation" (Potgieter-Groot et al., 2012). Penelitian di China menyatakan bahwa "... the majority of RCTs (Regular Classroom Teachers) have never received related training..." (Jia \& Santi, 2020). Penelitian di India menyatakan bahwa "...the issue of unskilled teachers and suggested that all teachers must be provided with relevant in-service training” (Bhatnagar \& Das, 20।4).

\section{Negative social attitudes}

Penelitian yang dilakukan di Pasifik menyatakan bahwa "... was negative attitudes and stigma towards children with disabilities" (Sharma et al., 20 I8). Serupa dengan hal tersebut, penelitian di Kepulauan Solomon (yang merupakan bagian dari Asia Pasifik) menyatakan bahwa "....negative attitudes and behaviour of the community also does not allow children with disabilities to attend schools, thus leading to discrimination against these children within the community environment"' (Sharma et al., 2017). Penelitian di Bangladesh menyatakan bahwa "Lack of social acceptance is a great barrier" (Kawser et al., 20/6). Serupa dengan penelitian tersebut, penelitian yang juga dilakukan di Bangladesh menyatakan bahwa "Most negative attitudes towards educating children with disabilities were related to the social stigma and prejudice about their abilities" (Ahsan et al., 20I2). Penelitian di Lithuania menyatakan bahwa "the dominance of prejudice and stereotypes limiting access to inclusive education; 'attitudes of society towards people with disabilities are still bad' and 'disability is like a "stamp" in life"' dan penelitian di Yunani menyatakan bahwa "disability in Greece is usually perceived as something negative, bad, incomplete, problematic', dan 'people with disabilities are ghettoized' dan 'feeling of refusal by the mainstream society"' (Genova, 20I5). Penelitian di China menyatakan bahwa "some RCTs still hold negative attitudes towards students with disabilities in their classrooms" (Jia \& Santi, 2020). Penelitian di India menyatakan bahwa "Many teachers are, however, unwilling to include special needs students in their classrooms" (Bhatnagar \& Das, 20 I4). 


\section{Accessibility issue}

Penelitian di Pasifik menyatakan bahwa "... a lack of adequate infrastructure within the community was highlighted as an important factor that created a barrier to inclusive education in the Pacific" (Sharma et al., 20 18). Senada dengan penelitian di Pasifik, penelitian di Kepulauan Solomon juga menyatakan bahwa "...current schools also lack infrastructures like ramps, proper toilets..." (Sharma et al., 20 I7). Penelitian di Bangladesh menyebutkan bahwa "Children in wheelchairs face problems as there is no ramp for them. Climbing stairs is not easy without ramps or slopes. Ramps and slopes should be in school to ensure accessibility, especially for wheelchair users. The toilets are not user-friendly. It is difficult for students to go to toilet with wheelchairs and other big equipments they use" (Kawser et al., 2016). Penelitian di Spanyol menyatakan bahwa "...physical access as the main barrier to inclusive education" dan di Lithuania menyatakan bahwa "The public transportation and accessibility of places most of the times are the biggest obstacles"' dan di Yunani menyatakan bahwa "accessibility is a core value for the proper implementation of any action, because without accessibility, you are excluded from every activity"' (Genova, 20I5). Penelitian di New Delhi, India, menyatakan bahwa "'They (special needs students) do not feel comfortable sitting in the classroom when their class is enjoying a television program in library on the second floor. They cannot go there in their wheelchairs as we do not have any lifts in the school"' (Bhatnagar \& Das, 20|4).

\section{Lack of awareness among people}

Penelitian yang dilakukan di Pasifik menyatakan bahwa “...emerged as barriers to inclusion. Disability within the community was stigmatized" dan "... due to a lack of awareness of inclusive education and externally imposed values" (Sharma et al., 20 18). Penelitian di Bangladesh menyatakan bahwa "Social awareness is important for any change in the society. But in our society misconceptions and prejudices exist among different people" (Kawser et al., 2016). Penelitian di Yunani menyatakan bahwa "'if schools do not present disability issues to children, they will never become aware citizens who know how to deal with people with disability' dan 'people are not sensitized to the difficulties that people with disability encounter"' (Genova, 20I5)

\section{Faulty policy making and problems in administration}

Penelitian di Pasifik menyatakan bahwa "Concerns surrounding the inadequacy of current policies appeared to be a consistent theme..." (Sharma et al., 20 18). Penelitian di Bangladesh menyatakan bahwa "They said that policy maker say that they will ensure the admission of the special need children and 'Education for All'. But in reality they do very little for these children. They do not change or modify their faulty policy according to the respondents" (Kawser et al., 2016). Penelitian di Spanyol menyebutkan bahwa "it introduces the term disability in a formal sense but does not protect the person's right to an inclusive education according to the social model of disability"' (Genova, 20I5). Penelitian di India menyatakan bahwa "One of the challenges facing inclusion in India today is the challenge of providing a single policy for the appropriate education for children and youth with special needs" (Das et al., 2012 dalam Bhatnagar \& Das, 20I4).

\section{Institutional power distance}

Penelitian di Pasifik menyatakan bahwa "A lack of government commitment was the final theme that appeared amongst..." (Sharma et al., 20l8). Senada dengan hal tersebut, penelitian di Kepulauan Solomon menyatakan bahwa "there was a lack or absence of policy, and also that in instances where such policy existed it was inadequately promoted and resourced" (Sharma et al., 2017). Penelitian di Bangladesh menyatakan bahwa "...institutional power distance as another barrier which created problems in their professional life as well" (Kawser et al., 2016). Penelitian di Yunani menyebutkan bahwa "'...the State lacks a policy for disability awareness and sensitization"' (Genova, 20I5). Penelitian di India menyatakan bahwa "...teachers do not know the goals and objectives of the special needs students as there was no policy in the school" dan "There are various institutions in India where students with disabilities are denied admission” (Bhatnagar \& Das, 20I4).

\section{Lack of teamwork}

Penelitian di Bangladesh menyatakan bahwa “... misconception and misunderstandings are the obstacles in team effort. For the lack of teamwork often policies for inclusive education do not see the light of implementation" (Kawser et al., 2016). Penelitian di Afrika Selatan menyatakan bahwa "The 
inability of the educators to meet and discuss issues about the learners experiencing learning barriers could also be attributed to lack of collaboration" (Abongdia et al., 20I5).

\section{Teacher's approach to identification/ Teacher's Knowledge}

Penelitian di Pasifik menyatakan bahwa "... a lack of teacher capability...” (Sharma et al., 2018). Penelitian di Lithuania menyatakan bahwa "'school teachers and university professors do not have the knowledge about the abilities of people with disabilities..." (Genova, 20I5). Penelitian di Afrika Selatan menyatakan bahwa "...the kind of training provided for teachers was not effective in ... identification of learners who experience barriers to learning" dan "It's difficult to say but we think he/she has got something wrong"' (Abongdia et al., 20 I5). Sependapat dengan hal tersebut, penelitian yang juga dilakukan di Afrika Selatan menyatakan bahwa "Some teachers lacked knowledge and understanding of emotional and behavioural barriers to learning" (Potgieter-Groot et al., 20I2). Penelitian di China menyatakan bahwa "...lack of related knowledge and ability to teach these students is one of the biggest barriers to promote inclusive education in current Chinese regular school context" (Jia \& Santi, 2020).

\section{Overcrowded classrooms}

Penelitian di Bangladesh menyatakan bahwa "student-to-teacher ratio is higher in the lower classes. And giving attention to each and every student becomes impossible for a teacher. Though government has declared that mainstream schools will allow tolerable special need children but schools are not seems to be interested to take such students" (Kawser et al., 2016). Penelitian di Afrika Selatan menyatakan bahwa "...the number of learners in this class is a problem on its own. ... makes it impossible for a teacher to be able to have access to all the learners" dan "I have 43 learners in my class and I can tell you that it is a nightmare"" (Abongdia et al., 20I5). Penelitian di China menyatakan bahwa "With already so many regular students in the class, putting one or two students with disabilities into the class will inevitably influences both the teaching of RCTs and learning of students with (out) disabilities" (Jia \& Santi, 2020). Penelitian di India menyatakan "....inclusion could be more successful if they had smaller class sizes in their schools, where fifty students in a class is a norm" (Bhatnagar \& Das, 2014).

\section{Parental Issue}

Penelitian di Afrika Selatan menyatakan bahwa “...parents would want to avoid stigmatisation on their children as much as possible which in a way may hinder the teachers from identifying the child's barrier to learning" (Abongdia et al., 20I5). Penelitian di China menyatakan bahwa “...nearly all parents spare no effort to facilitate their children to get a high score in school's various exams" (Jia \& Santi, 2020). Penelitian di India menyatakan bahwa "The parents of students with and without special needs pressurize the teachers, the principals and other staff in schools to make their own way" (Bhatnagar \& Das, 20I4).

\section{Immaterial nature}

Penelitian di Kepulauan Solomon menyatakan bahwa "'the geographical location of schools is a challenge. Consider children with physical disabilities crossing rivers and from the hills coming down to the coast to attend school"' (Sharma et al., 2017).

\section{Financial limitations}

Penelitian di Pasifik menyebutkan bahwa "... a lack of adequate funding... " (Sharma et al., 2018). Penelitian di Spanyol menyebutkan bahwa "the offer of services for people with disabilities has been reduced. The cut in education budgets in the last years "has reduced the number of support teachers, as well as auxiliary staff and professionals in the counselling teams and, therefore, the inclusion of children with disabilities in the general education system, bringing about an increasing of dropout"' (Genova, 20 I5). Penelitian di India menyatakan bahwa "...the state government allots a limited budget to each school for the education of children with special needs" (Bhatnagar \& Das, 20I4).

\section{Lack of differentiated instructions}

Penelitian di Pasifik menyatakan bahwa “... poor teaching pedagogies...” (Sharma et al., 2018). Penelitian di Bangladesh menyatakan bahwa "inflexible curriculum is a big problem for the special need children. A rigid syllabus is a great barrier of inclusive education" (Kawser et al., 2016). Peneltian di 
Lithuania menyebutkan bahwa "'school teachers and university professors do not have the knowledge about ... specific methods of knowledge transfer to the ones who are blind, deaf etc."' (Genova, 20I5). Penelitian di China menyatakan bahwa "...having no pedagogies for teaching students with disabilities" (Jia \& Santi, 2020). Penelitian di India menyatakan bahwa "...there is not a common curriculum in different states and therefore becomes difficult to make adaptations for children with special needs" (Bhatnagar \& Das, 20I4).

\section{Teacher anxiety}

Penelitian di China menyatakan bahwa "...they are afraid of 'with good intentions but doing something wrong"' dan "...teachers will be accused of doing wrong to their child by parents" (Jia \& Santi, 2020). Penelitian di India menyatakan bahwa "Many teachers were not sure whether inclusive education was a success in their schools. The teachers expressed their concerns about having stress and anxiety while including special needs students in their classrooms" (Bhatnagar \& Das, 20 I4).

\section{Fear of Downfall of Academic Achievement}

Penelitian di India menyatakan bahwa "In this age of increased academic competition, all the schools are competing to show their best results and this is the main reason that most teachers do not wish to include students with special needs in their classes. These students may not show good results and teachers do not wish to show such results" (Bhatnagar \& Das, 20I4).

Di bawah ini merupakan tabel daftar strategi yang dilakukan oleh berbagai negara untuk mengatasi hambatan dan tantangan dalam menyelenggarakan pendidikan inklusi di negaranya serta cara yang dilakukan untuk mengoptimalkan penyelenggaraan pendidikan inklusi, berdasarkan 7 jurnal penelitian hasil pencarian artikel ilmiah.

\section{Tabel III}

Tabel Strategi yang dilakukan oleh berbagai Negara untuk Mengoptimalkan Penyelenggaraan Pendidikan Inklusi (nomor disesuaikan dengan daftar jurnal pada tabel I)

\begin{tabular}{|c|c|c|c|c|c|c|c|}
\hline \multirow{2}{*}{ No. } & \multicolumn{7}{|c|}{ Strategi Mengoptimalkan Pendidikan Inklusi } \\
\hline & $\mathrm{T}$ & 2 & 3 & 4 & 5 & 6 & 7 \\
\hline I. & $\begin{array}{l}\text { Collabo- } \\
\text { rative } \\
\text { approach }\end{array}$ & $\begin{array}{l}\text { Improving } \\
\text { the quality } \\
\text { of in-service } \\
\text { teacher } \\
\text { education }\end{array}$ & $\begin{array}{l}\text { leadership } \\
\text { program- } \\
\text { mes }\end{array}$ & $\begin{array}{l}\text { Schoolba- } \\
\text { sed } \\
\text { profession- } \\
\text { nal } \\
\text { develop- } \\
\text { ment } \\
\text { program- } \\
\text { mes }\end{array}$ & $\begin{array}{l}\text { Developing a } \\
\text { policy } \\
\text { implementa- } \\
\text { tion plan that } \\
\text { provides } \\
\text { continued } \\
\text { support } \\
\text { during } \\
\text { implementa- } \\
\text { tion }\end{array}$ & $\begin{array}{l}\text { Govern- } \\
\text { ments to } \\
\text { commit to } \\
\text { a reason- } \\
\text { able } \\
\text { percenta-ge } \\
\text { of their } \\
\text { Gross } \\
\text { National } \\
\text { Product } \\
\text { towards } \\
\text { funding for } \\
\text { inclusive } \\
\text { education } \\
\text { in their } \\
\text { national } \\
\text { budgets }\end{array}$ & $\begin{array}{l}\text { raise } \\
\text { aware- } \\
\text { ness of } \\
\text { inclusive } \\
\text { educati- } \\
\text { on at a } \\
\text { national } \\
\text { level }\end{array}$ \\
\hline
\end{tabular}

Australia Awards South and West Asia (AASWA) Short Course programme.

The purpose of this AASWA short course was to build the capability and expertise of educators from South Asia in the technical components of inclusive education.

10. Further, the AASWA short course was designed to broaden understanding of a range of services, strategies, and providers of inclusive education in Australia that potentially could facilitate equitable access to education for children and youth with disabilities in the South Asia region (Beutel et al., 2018) (10 days training programmes for the practitioners in inclusive education).

\begin{tabular}{lllll}
\hline 5. & Curricu- & Emphasi- & human & resource \\
& lum & zing & resource & support \\
\hline
\end{tabular}




\begin{tabular}{|c|c|c|c|c|c|c|}
\hline & reform & $\begin{array}{l}\text { practicum } \\
\text { more than } \\
\text { theories }\end{array}$ & $\begin{array}{l}\text { develop- } \\
\text { ment } \\
\text { empower- } \\
\text { ring } \\
\text { institution- } \\
\text { nal heads to } \\
\text { implement } \\
\text { inclusion }\end{array}$ & & & \\
\hline 6. & \multicolumn{6}{|c|}{ Enhancing in-service teacher training on inclusive and special education } \\
\hline $\mathrm{II}$. & \multicolumn{6}{|c|}{ refugee-relevant CPD seminar } \\
\hline 7. & \multicolumn{6}{|c|}{ in-service training programme for teachers } \\
\hline 9. & $\begin{array}{l}\text { Aware- } \\
\text { ness } \\
\text { program- } \\
\text { mes }\end{array}$ & $\begin{array}{l}\text { Collabora- } \\
\text { tion } \\
\text { between } \\
\text { stakehold- } \\
\text { ers }\end{array}$ & $\begin{array}{l}\text { Infrastruc- } \\
\text { ture and } \\
\text { resource } \\
\text { provision }\end{array}$ & $\begin{array}{l}\text { Teacher } \\
\text { education } \\
\text { and } \\
\text { fostering } \\
\text { positive } \\
\text { attitudes }\end{array}$ & $\begin{array}{l}\text { Differentia- } \\
\text { ting } \\
\text { instruction }\end{array}$ & $\begin{array}{l}\text { Family } \\
\text { support }\end{array}$ \\
\hline
\end{tabular}

Berdasarkan hasil pencarian artikel ilmiah, beberapa negara sudah melakukan berbagai cara untuk meminimalisir hambatan dan tantangan dalam menyelenggarakan pendidikan inklusi dan strategi untuk mengoptimalkan pendidikan inklusi di berbagai negara.

\section{Strategi untuk Mengoptimalkan Pendidikan Inklusi di Kepulauan Pasifik}

Terdapat sebelas strategi yang ditemukan dalam penelitian yang dilakukan di Kepulauan Pasifik untuk mengatasi berbagai hambatan dan mengoptimalkan pendidikan inklusi. Strategi yang ada berdasarkan permasalahan dan hambatan yang dihadapi pada level micro (ruang kelas dan sekolah), meso (pedesaan dan komunitas), macro (sistem atau regional atau nasional). Pada level micro, strategi pertama yaitu peningkatan kualitas in-service teacher education dan strategi kedua yaitu leadership programmes untuk meningkatkan kemampuan guru dan pengetahuan guru tentang pembelajaran siswa di dalam kelas. Strategi ketiga yaitu mengembangkan school-based professional development programmes yang bertujuan untuk menyiapkan dan memonitor secara berkala kemajuan dari kemampuan dan pengetahuan guru. Strategi ini juga bisa digunakan untuk mengatasi hambatan sikap negatif dan stigma terhadap anak dengan disabilitas. Strategi keempat yaitu penerapan an inclusive education funding model with budgets untuk mengatasi permasalahan keterbatasan sumber daya. Strategi ini mendorong sekolah untuk dapat bekerjasama dengan organisasi non-pemerintah lokal dan sekolah khusus yang sudah lebih dulu ada. Strategi selanjutnya yaitu locating the curriculum in the Pacific context and using elements of the local cultures in the teaching and learning environment. Melibatkan pemimpin dan sesepuh komunitas lokal dalam aktivitas sekolah dapat memfasilitasi percepatan pendidikan inklusi di sekolah. Strategi ini dapat mengatasi hambatan kurangnya keinklusifan dari budaya lokal di kelas, sebagai akibat dari adanya mentalitas kolonial yang sudah menjadi budaya di ruang kelas (Sharma et al., 20I8).

Pada level meso, hambatan berupa sikap negatif dan kesadaran untuk mendukung praktik inklusi di dalam komunitas, strategi community education and awareness building programmes using multimedia drive perlu dikembangkan. Strategi ini akan mendukung dan mempromosikan keterlibatan pemimpin komunitas dan meningkatkan keterlibatan individu dengan disabilitas ke dalam aktivitas komunitas lokal. Pendekatan ini akan menjembatani kesenjangan antara komunitas dan sekolah serta menciptakan pemahaman yang lebih mendalam mengenai pentingnya pendidikan inklusi. Kurangnya program pendidikan guru, yang mengakibatkan pada kurangnya kemampuan guru dan cara pengajaran yang buruk dapat diatasi dengan menerapkan strategi re-conceptualisation of education in order to enhance the quality of teacher education. Pendidikan inklusi seharusnya tidak dipandang sebagai "tambahan" saja, tetapi lebih kepada menyetarakan kualitas pendidikan dan pemahaman sebagai satu kesatuan dalam sistem pembelajaran, terlebih karena kita semua berbeda dengan kebutuhan pembelajaran yang berbeda pula. Hambatan kurangnya infrastruktur yang memadai di dalam komunitas dapat diatasi dengan strategi adequate planning that focuses on 
improving transportation and mobility untuk memfasilitasi akses bagi mereka yang memiliki kebutuhan tambahan (Sharma et al., 2018).

Pada level macro, ketidaktepatan kebijakan pendidikan inklusi dapat diatasi dengan mengembangkan a policy implementation plan that provides continued support during implementation yang mampu mengurangi kebijakan yang tidak jelas. Hambatan keterbatasan finansial dapat diatasi dengan strategi $a$ need for governments to commit to a reasonable percentage of their Gross National Product towards funding for inclusive education in their national budgets. Terakhir, kurangnya komitmen pemerintah terhadap pendidikan inklusi dapat diatasi dengan raise awareness of inclusive education at a national level (contohnya seperti pertemuan dengan pemimpin negara dan stakeholders untuk memberikan informasi dan presentasi tentang keuntungan dari adanya pendidikan inklusi). Masyarakat di Kepulauan Pasifik yang terdiri dari pemimpin komunitas, individu dengan disabilitas maupun dengan kebutuhan khusus juga harus menyuarakan tentang pentingnya pendidikan inklusi ini, sehingga dapat meningkatkan kesediaan pemerintah untuk merealisasikan kebijakan-kebijakan yang ramah terhadap individu dengan disabilitas dan pendidikan inklusi (Sharma et al., 20।8).

\section{Strategi untuk Mengoptimalkan Pendidikan Inklusi di Kepulauan Solomon}

Terdapat enam strategi yang ditemukan dalam penelitian yang dilakukan di Kepulauan Pasifik untuk mengatasi berbagai hambatan dan mengoptimalkan pendidikan inklusi. Strategi pertama yaitu dengan menyelenggarakan awareness programmes tentang disabilitas. Program ini dipandang dapat meningkatkan kesadaran masyarakat mengenai disabilitas, walaupun dalam praktiknya membutuhkan kehati-hatian agar program dapat berjalan dengan baik. Program ini sebaiknya dilaksanakan secara tokenistic, misal adanya program "Satu Hari dengan Kursi Roda" bagi individu non-tuna daksa. Program ini lebih meningkatkan keterlibatan individu dengan tuna daksa dan memberikan kesempatan terjadinya pertukaran pemahaman yang saling menguntungkan. Pengalaman tersebut haruslah pengalaman yang otentik, tanpa ada paksaan. Strategi kedua yaitu kolaborasi antara stakeholders. Kolaborasi ini merupakan budaya utama dan budaya tradisional yang ada di Kepulauan Solomon, juga Kepulauan Pasifik dimana Kepulauan Solomon berada. Stakeholder yang ada di Kepulauan Solomon dipegang oleh komunitas lokal, dimana komunitas lokal masih menganut dengan komunitas gereja. Gereja menjadi pusat bagi kehidupan orang-orang di Kepulauan Solomon, dalam hal ini juga menjadi salah satu faktor keberhasilan pendidikan inklusi dan juga meningkatkan kondisi individu dengan disabilitas secara umum. Strategi ketiga yaitu kesediaan infrastruktur dan sumber daya. Strategi ini memberikan pemahaman kepada sekolah umum bahwa sekolah butuh mempersiapkan diri untuk dapat menerima siswa dengan disabilitas dimana persiapan ini membutuhkan prasarana seperti bidang miring, toilet khusus untuk disabilitas, dan sarana seperti materi dan bahan pembelajaran yang disesuaikan dengan kebutuhan siswa dengan disabilitas (Sharma et al., 2017).

Strategi keempat yaitu pendidikan guru inklusi dan pengembangan sikap positif. Ada banyak penelitian yang menyebutkan bahwa hambatan dalam penyelenggaraan pendidikan inklusi yaitu kurangnya pengetahuan guru tentang pendidikan inklusi dan masih adanya sikap negatif guru terhadap siswa dengan disabilitas. Perlu adanya pelatihan yang dapat meningkatkan pengetahuan guru dan dapat mengembangkan sikap positif terhadap siswa dengan disabilitas. Strategi kelima yaitu pembedaan instruksi. Guru yang memiliki pendidikan yang berkualitas, akan mampu melakukan instruksi yang berbeda kepada siswa tanpa disabilitas dan kepada siswa dengan disabilitas, sehingga dalam satu waktu pembelajaran, guru dapat menjangkau semua siswa di kelas inklusi. Pemberian pendidikan inklusi kepada guru di Kepulauan Solomon lebih mudah daripada negara lainnya, karena Kepulauan Solomon memiliki tingkat keragaman pendidikan guru yang kecil karena hanya ada satu universitas yang mendidik para calon guru, yaitu Solomon Islands National University. Universitas ini juga mendukung pendidikan guru inklusi dan memfaslitasi penelitian. Sehingga guru yang lulus dari universitas ini sudah memiliki pengetahuan, sikap, dan keterampilan yang dibutuhkan untuk menjadi guru inklusi yang baik. Strategi terakhir yaitu adanya dukungan keluarga. Strategi ini penting diterapkan karena banyak orangtua yang kurang mempercayai guru dan sekolah untuk dapat memberikan pendidikan, kepedulian, dan dukungan kepada anak dengan disabilitas. Selain itu, kurangnya komitmen orangtua untuk menyekolahkan anaknya dengan disabilitas di sekolah inklusi menjadi salah satu perhatian dalam penelitian ini (Sharma et al., 2017). 


\section{Strategi untuk Mengoptimalkan Pendidikan Inklusi di Afrika Selatan}

Guru diberikan intervensi yang terdiri dari tiga sesi jangka pendek. Sesi pertama yaitu guru inklusi bebas mengekspresikan semua kebutuhan dan pengalamannya ketika mengajar siswa dengan gangguan emosi dan perilaku. Dilanjutkan dengan sesi kedua yaitu pemberian informasi yang dapat memperkaya pemahaman guru mengenai kebutuhan belajar siswa dengan gangguan emosi dan perilaku. Informasi spesifik dan informasi tambahan juga diberikan pada sesi kedua. Pengalaman bertukar informasi juga menginspirasi para guru dalam menerapkan strategi baru di kelasnya. Selanjutnya pada sesi ketiga mendiskusikan tentang strategi apa yang dapat dilakukan untuk mendukung pembelajaran siswa dengan gangguan emosi dan perilaku. Beberapa guru tertarik untuk memahami bagaimana mengimplementasikan strategi seperti problem solving, latihan relaksasi, dan latihan keterampilan sosial. Guru melakukan diskusi panjang mengenai bagaimana mengimplementasikan alternatif pemberian hukuman jika siswa dengan gangguan emosi dan perilaku menunjukkan sikap yang melebihi batas. Informasi mengenai hukuman berupa time-out diberikan kepada guru karena guru kurang familiar dengan pemberian hukuman ini (PotgieterGroot et al., 2012).

Intervensi berupa short-term three-session telah cukup memberikan pengetahuan kepada guru inklusi mengenai pengetahuan dan keterampilan dasar untuk menangani siswa dengan gangguan emosi dan perilaku. Pengalaman ini sangat berharga terhadap in-service teacher yang belum pernah mendapat pelatihan sebelumnya mengenai bagaimana cara menangani siswa dengan gangguan emosi dan perilaku. Intervensi ini meningkatkan pengetahuan dan kesadaran guru tentang kebutuhan siswa. Pengetahuan ini dapat membantu guru mengubah cara bersikap terhadap pembelajar dan membangun hubungan yang suportif (Potgieter-Groot et al., 20I2).

\section{Strategi untuk Mengoptimalkan Pendidikan Inklusi di China}

Strategi yang direkomendasikan oleh RCT (Regular Classroom Teacher) yaitu adanya pelatihan inservice teacher mengenai pendidikan inklusi dan pendidikan khusus. Strategi ini direkomendasikan karena RCT tidak memiliki pengetahuan sama sekali mengenai pendidikan inklusi selama mengikuti program pendidikan guru in-service. Lebih buruk lagi, program pendidikan guru in-service hanya memberikan sedikit bahkan tidak ada sama sekali perhatian terhadap pendidikan inklusi dan pendidikan khusus yang akhirnya membuat guru tidak bisa mengajar siswa dengan disabilitas di dalam kelas, tidak bisa menggunakan perlengkapan mengajar yang lengkap dan tersedia ruangan sumber, dan tidak mengetahui apa itu pendidikan inklusi. Ada tiga hal yang menjadi prioritas untuk diberikan pada saat pelatihan guru in-service. Pertama, pengetahuan dasar mengenai pendidikan inklusi dan pendidikan khusus. Contohnya, arti dan makna dari pendidikan inklusi, perkembangan pendidikan inklusi di seluruh dunia, kebijakan pendidikan inklusi di China, dan sebagainya. Hal ini dapat mengubah cara berpikir lama dari RCT, seperti pandangan yang kurang menyeluruh mengenai siswa dengan disabilitas, sekolah umum untuk $99 \%$ siswa normal, dan sebagainya. Kedua, pelatihan harus memberikan pengetahuan spesifik tentang disabilitas dan keterampilan yang dibutuhkan untuk dapat memenuhi kebutuhan belajar siswa dengan disabilitas. Prioritas kedua ini muncul karena RCT membutuhkan pengetahuan yang lebih mengenai disabilitas, seperti penyebab dan gejala perilaku yang muncul pada anak dengan autisme, keterampilan tertentu seperti menulis dan membaca huruf Braille, menggunakan bahasa isyarat dan penggunaan bahan pembelajaran yang sesuai yang ada di ruang sumber. Ketiga, yaitu bagaimana untuk berkolaborasi dengan guru pendidikan khusus. Prioritas ini dibuat karena guru sama sekali tidak mengetahui bagaimana caranya untuk bekerja bersama secara efektif dengan guru pendidikan khusus untuk meningkatkan kondisi dan situasi siwa dengan disabilitas. Contohnya seperti bagaimana untuk mengikutsertakan guru pendidikan khusus ke dalam pembelajaran kelas RCT, bagaimana untuk mendesain rencana pembelajaran bersama, dan sebagainya (Jia \& Santi, 2020).

\section{Strategi untuk Mengoptimalkan Pendidikan Inklusi di Bangladesh}

Terdapat lima strategi yang ditemukan dalam penelitian yang dilakukan di Bangladesh untuk mengatasi berbagai hambatan dan mengoptimalkan pendidikan inklusi. Strategi pertama yaitu adanya reformasi kurikulum. Strategi ini muncul karena kurikulum pendidikan guru pre-service yang sudah ada tidak memiliki informasi yang cukup mengenai bagaimana mengajar bahan pelajaran dengan cara yang berbeda di dalam satu kelas. Reformasi kurikulum ini bisa dilakukan dengan cara 
menghubungkan bahan pembelajaran dengan cara mengajar kepada siswa, penambahan informasi yang berkaitan dengan pendidikan inklusi di dalam kurikulum, penambahan pendekatan yang berfokus pada anak dan psikologi anak di dalam kurikulum, penambahan yang menekankan pada implementasi strategi daripada teoritis, merevisi kurikulum yang sudah ada yang didesain untuk persiapan guru dalam mengajar tingkat pendidikan primer dan sekunder, meningkatkan durasi pelatihan pendidikan guru pre-service, memastikan penggunaan teknologi di dalam pendidikan, dan merevisi sistem asesmen yang masih berdasar pada hafalan. Strategi kedua yaitu mengkontekstualisasikan proses belajar-mengajar. Strategi ini muncul karena sistem pendidikan terpusat yang terkontrol dan rigid diidentifikasi sebagai hambatan dalam mengimplementasikan pendidikan inklusi oleh guru. Untuk menjawab hambatan ini, perlu strategi dimana guru pre-service diberikan kebebasan dan otoritas untuk mengaplikasikan pendekatan belajar-mengajar yang berorientasi pada konteks (Ahsan et al., 20I2).

Strategi ketiga yaitu kesempatan untuk meningkatkan praktikum daripada teoritis. Strategi ini muncul untuk memberikan kesempatan kepada guru pre-service mengajar siswa dengan kemampuan yang berbeda-beda di dalam setting inklusi. Rekrutmen guru pendidik tambahan juga diperlukan untuk dapat mengimplementasikan strategi ini dengan cara meningkatkan aktivitas yang dapat menambah kesadaran mengenai pentingnya praktikum untuk memastikan kerjasama yang baik antara guru pre-service dan guru pendidik tambahan. Strategi keempat yaitu pelatihan administrator pendidikan. Strategi ini muncul karena adanya transfer guru dimana guru pembelajaran tidak membutuhkan latar belakang pendidikan yang sesuai dengan pembelajaran yang diampu. Sehingga guru tidak memiliki pengetahuan dan latar belakang tentang pendidikan guru dan pembelajaran siswa sebelum mengambil posisi administratif di dalam institusi. Hal ini menjadi hambatan baik pada tingkat pendidikan primer maupun sekunder. Akhirnya muncul revisi mengenai kebijakan rekrutmen di dalam institusi. Strategi terakhir yaitu dukungan sumber daya. Dukungan ini dapat berupa peningkatan sumber belajar di perpustakaan yang berhubungan dengan pendidikan inklusi, awareness-raising programmes dalam pendidikan inklusi, memastikan fasilitas yang dapat diakses di dalam sekolah, memastikan dukungan perangkat yang dapat memandu ke sekolah, meningkatkan motivasi komunitas terhadap inklusi, memastikan dukungan guru tambahan dan ahli, meningkatkan kebijakan pemerintah lokal yang ramah terhadap pendidikan inklusi, memastikan penerimaan teman di antara siswa, membangun kolaborasi dan kerjasama secara internasional, mengembangkan hubungan antara pendidikan umum dan khusus serta mengembangkan hubungan antara program pendidikan guru pre-service dan in-service (Ahsan et al., 20 I 2).

\section{Strategi untuk Mengoptimalkan Pendidikan Inklusi di Nepal, Sri Lanka, dan Bangladesh}

Program Short Course AASWA (Australia Awards South and West Asia) dilaksanakan selama dua minggu (IO hari) yang terdiri dari komponen praktik dan kebijakan pendidikan inklusi, yang diadakan di Australia dengan dukungan online dari para akademisi universitas di Australia kepada partisipan ketika sudah kembali ke negara asal. Workshop follow-up dilakukan di Nepal enam bulan setelah dilakukan program short course. Konten program menggunakan tiga dimensi yang menjadi kunci dalam kerangka Index for Inclusion, yaitu developing inclusive policies, fostering inclusive cultures, dan evolving inclusive practices. Struktur program terdiri dari aktivitas workshop, kunjungan ke sekolah percontohan yang menyelenggarakan prinsip dan praktik inklusi, percakapan reflektif, dan rencana profesional yang dibuat oleh partisipan ketika kembali ke negara asal untuk diimplementasikan sesuai dengan konteks negara asalnya. Kegiatan networking terstruktur juga diberikan untuk mengenalkan beberapa pendidik yang memiliki keahlian dalam pendidikan inklusi kepada partisipan (Beutel et al., 2018).

Sebelum kegiatan pertama short course dimulai, penting untuk memiliki pemahaman yang sama mengenai pendidikan inklusi antara partisipan dan materi program. Dalam hal ini, partisipan terlibat dalam aktivitas perkenalan dimana partisipan dikenalkan kembali dengan kebijakan pendidikan saat ini, budaya, dan praktik pendidikan di Nepal, Sri Lanka, dan Bangladesh. Aktivitas ini bertujuan agar semua partisipan memiliki pemahaman bersama dan tujuan terhadap pendidikan inklusi. Penting juga untuk memiliki kesadaran mengenai pengetahuan dan pemahaman sebelumnya tentang pendidikan inklusi. Dalam hal ini, partisipan membagikan perjalanan dan pengalamannya di dalam 
pendidikan inklusi kepada pemimpin program. Partisipan didorong untuk dapat terlibat dan berpartisipasi aktif selama pelaksanaan program dengan cara pergantian pemimpin yang bergilir setiap hari selama sepuluh hari. Tugas pemimpin yaitu sebagai pengatur waktu kelompok, penghubung antara pemimpin program dan pihak kesejahteraan tentang berbagai kekhawatiran atau tantangan yang dihadapi oleh kelompok, dan memulai hari dengan aktivitas laporan singkat mengenai hal-hal pokok yang dipelajari pada hari sebelumnya melalui foto dan presentasi. Selanjutnya, partisipan terlibat dalam kegiatan workshop yang membahas tentang trend dan kebijakan dalam pendidikan inklusi di seluruh dunia, memahami macam-macam jenis disabilitas seperti autisme, gangguan intelektual, dan kesulitan belajar serta dikenalkan dengan macam-macam model inklusi untuk mendukung pembelajar yang memiliki perbedaan karakteristik dan kebutuhan pembelajaran. Terdapat workshop dan diskusi mengenai action learning dan mentoring dalam pendidikan inklusi serta pertemuan interaktif dengan otoritas pendidikan lokal yang terlibat dalam pendidikan inklusi dan dukungan terhadap disabilitas. Partisipan juga berkontribusi setiap hari untuk membuat pembelajaran personal dan jurnal perencanaan aksi dengan refleksinya terhadap tujuan pembelajaran personal, kunci pembelajaran, dan pengalaman serta menetapkan koneksi untuk mendukung pengembangan RWP (Return to Work Plan) (Beutel et al., 20l8).

\section{Strategi untuk Mengoptimalkan Pendidikan Inklusi di Republik Ceko}

Strategi untuk mengatasi hambatan yang dihadapi dalam penyelenggaraan pendidikan inklusi di Republik Ceko yaitu dengan memberikan seminar yang relevan mengenai konteks pengungsi dari Burma (Myanmar). Anak pengungsi yang berusia 18 tahun ke bawah merupakan siswa inklusi karena bahasa pertamanya bukan bahasa Ceko, pendidikan awal mungkin berbeda secara signifikan, anak dan keluarganya yang mengalami trauma, terisolasi secara budaya dan bahasa, tanpa keluarga besar atau informasi dari tetangga sebelah mengenai negara baru mereka, dan tidak membuat keputusan yang memiliki tujuan dan informasi secara lengkap mengenai perpindahan ke Republik Ceko. Hal ini menimbulkan kebutuhan akan adanya dukungan, empati secara emosional, pemahaman dan pengetahuan budaya dan bahasa yang lebih luas dari sekolah, guru, dan guru pendidik. Penelitian terbagi menjadi 2 part, dimana part I lebih dominan membahas tentang tantangan dan hambatan yang dialami selama melangsungkan pendidikan inklusi, dan part 2 lebih dominan membahas tentang strategi apa yang bisa dilakukan ketika menghadapi hambatan yang telah diidentifikasi pada part I. Part 2 dilakukan 2 kali, yaitu 3 bulan sebelum sekolah menerima siswa pengungsi dengan mengadakan seminar yang relevan dengan konteks pengungsi (refugeerelevant in-service seminar) dan 5 bulan setelahnya ( 2 bulan setelah sekolah menerima siswa pengungsi) untuk melihat keberhasilan seminar. Seminar dilakukan selama sehari penuh yang dihadiri secara sukarela oleh 15 orang guru dan 15 orang perwakilan dari Kementerian Pendidikan (Ministry of Education/ MoE), Ministry of Interior, Refugee Facility Administration, dan regional education authorities. Setelah itu, ada juga staf dari dua sekolah yang menghadiri in-service training (INSET) selama tiga hari penuh untuk membahas tentang pendidikan anak imigran, pendidikan multikultural, dan teknik mengajar CzAL. Respon positif diberikan oleh guru yang mengikuti seminar dan INSET (Bačáková \& Closs, 2013).

Konten dari seminar terdiri dari beberapa informasi, diantaranya yaitu: (I) The individual refugee children, yang membahas tentang riwayat pendidikan, keluarga, bahasa, minat, kekuatan, kebutuhan khusus, dan sebagainya; (2) Educational support measures and how to use them optimally, yang membahas tentang pendampingan pembelajaran, PPI (Program Pembelajaran Individual), kegiatan setelah sekolah, kelompok belajar, dukungan teman sebaya, asesmen formatif, Czech as an additional language (CzAL), ketersediaan bahan pembelajaran yang tepat, dan sebagainya; (3) Communication strategies with parents, yang membahas tentang mempekerjakan penerjemah, pertemuan dengan orangtua, melibatkan semua orangtua dalam sekolah, terutama mereka yang kurang familiar dengan sistem pendidikan di Republik Ceko, termasuk orangtua pengungsi; (4) The experience of being refugees, yang membahas tentang dampak yang mungkin terjadi dari trauma dan isolasi terhadap proses pembelajaran, perilaku, dan sebagainya dari anak dan orangtua; (5) Opportunities for future CPD, yang membahas tentang ketersediaan untuk dilakukan CPD lebih lanjut dalam pendidikan multikultural, pendidikan imigran, dan CzAL; (6) Available funding resources, yang membahas tentang ketersediaan dana yang dimiliki sekolah ketika menerima siswa pengungsi, siswa 
dengan kebutuhan pendidikan khusus (special education needs/ SEN) dan sebagainya dengan saran untuk mengakses dan mengoptimalkan dukungan finansial; (7) Grade placement, yang membahas tentang nilai penting dari penempatan kelas yang sesuai dan tepat terhadap usia anak dan riwayat pendidikan; dan (8) Induction programmes, yang membahas tentang konten program induksi yang memungkinkan untuk siswa pengungsi dan orangtuanya dengan materi yang dapat digandakan, bagaimana untuk menyiapkan kelas untuk teman sekelas siswa pengungsi yang baru (Bačáková \& Closs, 2013).

\section{Pembahasan}

Setiap daerah dan negara memiliki tantangan dan hambatannya masing-masing dalam menyelenggarakan pendidikan inklusi. Solusi dan strategi yang ditawarkan oleh tiap negara juga bervariasi. Terdapat beberapa hal yang bisa ditarik 'benang merah' dari penjabaran hasil diatas, yaitu beberapa tantangan yang secara mayoritas masih dihadapi oleh beberapa negara dalam menyelenggarakan sekolah inklusi, yaitu adanya sikap negatif seperti pemberian stigma yang buruk bahkan menganggap individu dengan disabilitas merupakan 'something negative, bad, incomplete, problematic, 'stamp' in life' (Genova, 20I5). Hal ini semakin memperburuk kondisi ketidakmampuan individu dengan disabilitas karena mereka harus menanggung dua beban sekaligus, yaitu beban disabilitas dan beban stigma yang ditujukan pada mereka.

Selain adanya sikap negatif, adanya keterbatasan aksesibilitas fasilitas umum seperti toilet, transportasi umum, dan bangunan bertingkat juga menjadi permasalahan bagi individu dengan disabilitas fisik. Tidak adanya bidang landai/ bidang miring maupun lift menjadi penghambat bagi mereka yang memiliki disabilitas fisik maupun mereka yang menggunakan kursi roda (Bhatnagar \& Das, 20I4; Genova, 20I5). Hasil penelitian mengungkapkan kekesalan partisipan mengenai tidak adanya fasilitas umum yang ramah terhadap disabilitas karena ketidakkonsistenan antara kebijakan yang dibuat oleh pemerintah untuk mengajak para disabilitas dalam rangka turut produktif seperti orang normal pada umumnya tetapi pemerintah tidak menyediakan fasilitas umum yang ramah bagi penderita disabilitas. Bagi mereka, kebijakan yang dibuat oleh pemerintah hanya sekedar kebijakan saja dan tidak ada praktek di lapangan yang cukup berarti untuk membuat individu dengan disabilitas dapat berfungsi dan produktif seperti orang normal lainnya (Genova, 20 I 5; Kawser et al., 20I6). Diskriminasi terhadap individu dengan disabilitas masih ada di dalam kerangka kebijakan nasional, dan pada level institusional, hal tersebut menjadi 'benang merah' antara level micro (pengalaman individu), meso (kebijakan nasional), dan macro (kebijakan EU 2020, di Benua Eropa) (Genova, 20I5).

Permasalahan lainnya yang juga banyak dialami oleh negara-negara dalam menyelenggarakan pendidikan inklusi yaitu kurangnya pengetahuan guru tentang sekolah inklusi dan disabilitas. Guru kurang memahami bagaimana cara memberikan pemahaman yang tepat kepada siswa dengan ketunaan, seperti tuna rungu dan tuna netra (Genova, 20I5). Selain itu, kurangnya pelatihan atau kurang efektifnya pelatihan kepada guru di sekolah inklusi juga menjadi persoalan yang masih saja dihadapi oleh banyak negara, baik negara berkembang maupun negara maju. Pelatihan yang diberikan hanya berupa formalitas sebagai bukti tanpa melihat efektifitas dan perbaikan yang dihasilkan setelah pelatihan diberikan (Abongdia et al., 20I5).

Terdapat beberapa konteks yang unik yang hanya terjadi di negara tertentu, contohnya China. Penelitian yang dilakukan di China menyebutkan bahwa orangtua dari anak dengan disabilitas lebih menekan guru dan pihak sekolah untuk memberikan pendidikan yang terbaik kepada anaknya sesuai dengan keinginannya karena adanya kebijakan satu keluarga dengan satu anak yang akhir akhir ini menjadi kebijakan di Negara China (jia \& Santi, 2020). Keluarga menekankan pendidikan yang layak untuk anaknya karena anak satu-satunya inilah yang akan menentukan nasib dari dirinya sendiri dan menentukan derajat kedua orangtuanya di kemudian hari jika berhasil, dan hal tersebut masih menjadi keyakinan masyarakat China hingga saat ini. Orangtua tidak terlalu bertanggungjawab untuk memberikan pendidikan di luar sekolah, sehingga apabila sekolah tidak bisa memberikan pendidikan yang terbaik untuk anaknya, maka orangtua akan menyalahkan guru dan pihak sekolah. Hal ini juga yang menjadi latar belakang dibalik sikap pengabaian guru reguler 
terhadap anak dengan disabilitas. Apabila guru salah atau kurang tepat dalam memberikan instruksi dan pembelajaran kepada anak dengan disabilitas, maka orangtua yang akan menyalahkan guru, terlepas dari niat baik yang dimiliki oleh guru untuk mendidik dan memberikan pembelajaran kepada anak dengan disabilitas (dimana niat baik berbuah menjadi bumerang terhadap diri guru). Di sisi lain, guru tidak dibekali dengan pemahaman tentang sekolah inklusi dan tidak diberikan pelatihan untuk memberikan instruksi yang tepat dan penggunaan sumber belajar (walaupun tersedia di sekolah) secara tepat kepada anak dengan disabilitas (Jia \& Santi, 2020). Alasan ini pula yang membuat guru kelas merekomendasikan pelatihan in-service teacher kepada guru RCT (Regular Classroom Teacher). Pelatihan ini membekali guru dengan pengetahuan dasar tentang pendidikan inklusi dan pengetahuan spesifik tentang disabilitas, keterampilan yang dibutuhkan untuk dapat memenuhi kebutuhan belajar siswa dengan disabilitas termasuk penggunaan bahan pembelajaran yang sesuai yang ada di ruang sumber, dan pengetahuan tentang bagaimana untuk berkolaborasi dengan guru pendidikan khusus. Pelatihan ini akan meminimalisir peluang siswa dengan disabilitas dibiarkan dan diabaikan begitu saja hanya karena kurangnya keterampilan dan ketidaktahuan guru mengenai pendidikan inklusi. Konteks ini berbeda dengan konteks di Indonesia. Tidak ada pembatasan yang sangat ketat mengenai jumlah anak maksimal yang bisa dan boleh dimiliki oleh sebuah keluarga, walaupun terdapat anjuran dari Badan Kependudukan dan Keluarga Berencana Nasional (BKKBN) mengenai pembatasan jumlah anak dalam satu keluarga, yaitu 'dua anak cukup' (Yatim, 20I5). Namun pelatihan kepada guru kelas mengenai penggunaan sumber belajar yang dapat menunjang keberlangsungan pendidikan inklusi menjadi contoh strategi yang dapat diaplikasikan di Indonesia, seperti pelatihan guru kelas membaca huruf braille dan penggunaan media huruf braille untuk siswa dengan tuna netra, pelatihan guru kelas mempelajari bahasa isyarat untuk siswa dengan tuna rungu, pelatihan guru kelas mempelajari kartu komunikasi untuk siswa dengan tuna wicara, dan pelatihan guru kelas mempelajari media audiotape untuk siswa dengan tuna daksa yang memiliki hambatan terhadap kehadiran di sekolah karena menjalani terapi dan operasi.

Konteks berbeda ditemukan pada penelitian di Afrika Selatan. Di negara tersebut, anak dengan disabilitas lebih banyak tidak melanjutkan sekolah karena jumlah kelas yang besar dan tidak adanya dukungan dari orangtua. Orangtua anak dengan disabilitas lebih cenderung untuk 'menyimpan' anaknya di rumah dan tidak disekolahkan karena ketakutan dan kekhawatiran stigma yang akan didapat oleh anak. Selain itu, orangtua juga menghindari stigma tentang anaknya sebisa mungkin yang dapat menghindarkan guru dari mengidentifikasi hambatan yang dialami oleh anak dalam pembelajaran dengan mengatakan bahwa anaknya sangat pintar ketika berada di rumah (Abongdia et al., 20I5). Untuk menghadapi hal ini, perlu adanya awareness programmes tentang disabilitas yang dipandang dapat meningkatkan kesadaran masyarakat mengenai disabilitas (Sharma et al., 2017) dan school-based professional development programmes yang bisa digunakan untuk mengatasi hambatan sikap negatif dan stigma terhadap anak dengan disabilitas (Sharma et al., 2018). Selain itu, perlu ada dukungan keluarga, karena orangtua kurang berkomitmen untuk menyekolahkan anak dengan disabilitas di sekolah inklusi (Sharma et al., 2017). Awareness programmes sudah pernah dilakukan di Indonesia seperti perayaan World Awareness Day yang merayakan World Down Syndrome Day yang diselenggarakan pada tanggal 2 I Maret setiap tahunnya, World Autism Awareness Day yang diselenggarakan pada tanggal 2 April setiap tahunnya, hingga International Day of Persons with Disabilities yang diselenggarakan pada tanggal 3 Desember setiap tahunnya. Perayaan ini akan terus berlanjut sebagai tongkat estafet yang dapat meningkatkan kesadaran masyarakat mengenai disabilitas. Hanya saja, perlu sebuah inovasi lebih spesifik yang perlu dilakukan, seperti adanya program 'a day in a wheelchair' yang pesertanya merupakan anak, remaja, maupun dewasa 'normal' yang harus menghabiskan satu hari penuh di atas kursi roda dan harus tetap melaksanakan aktivitas sehari-hari seperti orang 'normal' lainnya. Semua kegiatan yang dilakukan dapat diliput dan disiarkan ke stasiun televisi nasional sehingga program ini diketahui oleh banyak kalangan dan mampu memberikan perspektif mengenai apa yang dipikirkan dan dirasakan oleh individu dengan ketunaan tertentu, dalam kasus ini yaitu tuna daksa.

Pelatihan yang sudah pernah dilakukan kurang efektif untuk menyelesaikan tantangan yang dihadapi selama mengajar di kelas inklusi (Abongdia et al., 20I5) dan belum pernah mendapatkan pelatihan 
yang sesuai dengan permasalahan yang dihadapi, yaitu siswa dengan gangguan emosi dan perilaku (Potgieter-Groot et al., 20I2). Pelatihan yang diberikan kepada guru berupa short-term three-session telah cukup memberikan pengetahuan kepada guru inklusi untuk dapat menyelesaikan permasalahan dan hambatan dalam menangani siswa dengan gangguan emosi dan perilaku. Pelatihan ini sangat berharga terhadap in-service teacher karena dapat meningkatkan pengetahuan dan kesadaran guru tentang kebutuhan siswa sehingga membantu guru mengubah cara bersikap terhadap pembelajar dan membangun hubungan yang suportif terhadap siswa dengan gangguan emosi dan perilaku (Potgieter-Groot et al., 20I2). Selain itu, perlu adanya kontekstualisasi proses belajar-mengajar yang terlalu rigid sehingga guru memiliki otoritas dan kebebasan namun tetap terkontrol untuk mengaplikasikan pendekatan belajar-mengajar yang berorientasi pada konteks (Ahsan et al., 20I2).

Konteks yang bisa dipahami dari penelitian di Pasifik yaitu jumlah penduduk yang relatif sedikit namun secara geografi, luas daerah Pasifik (yang mencakup Fiji, Samoa, Kepulauan Solomon, Vanuatu, dan Tonga) hampir sekitar I5\% dari total luas permukaan bumi (World Bank, 2018). Jumlah penduduk yang relatif sedikit masih harus ditambah dengan kondisi alam Kepulauan Pasifik yang rapuh karena terpapar perubahan iklim, kenaikan suhu, pemanasan air laut, peningkatan permukaan laut disertai dengan banjir di pesisir pantai dan erosi, serta perubahan iklim yang ekstrim. Mengetahui bahwa ada banyak tantangan yang dihadapi, para pemangku kebijakan saling bekerjasama untuk mewujudkan pendidikan inklusi. Negara-negara yang terletak di Kepulauan Pasifik saling bekerjasama dalam mengidentifikasi strategi penyelenggaraan pendidikan inklusi dalam lingkup regional untuk mengimplementasikan kerangka kebijakan regional dan nasional. Tidak mengherankan jika ada beberapa kebijakan yang hampir mirip dengan kebijakan yang ditemui di satu tempat dengan tempat lain di Kepulauan Pasifik (Sharma et al., 20 I8). Strategi yang dilakukan untuk mengatasi hambatan penyelenggaraan Pendidikan Inklusi di Kepulauan Solomon bervariasi, seperti rencana implementasi kebijakan yang memberikan dukungan berkelanjutan selama proses implementasi di lapangan, komitmen dari pemerintah untuk memberikan sebagian prosentase dari Gross National Product (GNP) sebagai sumber dana pendidikan inklusi dalam rancangan budgeting nasional, dan pertemuan dengan stakeholders untuk memberikan informasi tentang keuntungan dari adanya pendidikan inklusi (Sharma et al., 20 I8). Strategi ini memerlukan kerjasama dan kolaborasi dengan stakeholders untuk mempercepat keberhasilan pendidikan inklusi dan meningkatkan kondisi individu dengan disabilitas secara umum (Sharma et al., 2017). Bahkan, jika memungkinkan perlu adanya kerjasama dan kolaborasi secara internasional (Ahsan et al., 20I2). Di Indonesia, perlu budgeting khusus yang dialokasikan untuk pembiayaan pelatihan guru kelas sehingga dapat mengajar di kelas inklusi, sekian persen anggaran belanja negara digunakan untuk membangun fasilitas umum yang lebih ramah terhadap disabilitas seperti angkutan umum yang memberikan ruang yang cukup luas untuk individu dengan tuna daksa yang menggunakan kursi roda, bidang landai/ bidang miring dan lift umum, serta guiding block untuk individu dengan tuna netra.

Salah satu hal unik didapatkan dari penelitian di Australia, yaitu adanya kerjasama antar negara, bahkan antar benua, untuk dapat meningkatkan pengetahuan, keterampilan, dan kualitas pendidikan inklusi yang melibatkan pemangku kebijakan dan organisasi non-pemerintah dari negara-negara di Asia Selatan seperti Nepal, Sri Lanka, dan Bangladesh (Nepal= 7 peserta, Bangladesh=3 peserta, dan Sri Lanka=I peserta) yang diundang untuk mengikuti pelatihan Australia Awards South and West Asia (AASWA) Short Course programme selama 10 hari penuh. Hasil penelitian menghasilkan keinginan dari peserta pelatihan untuk segera menerapkan strategi penyelenggaraan sekolah inklusi di tempatnya masing-masing, sesuai dengan konteks lingkungan sekitar yang tertulis di dalam RWP (Return to Work Plan). Peserta juga mendapatkan manfaat dari mengikuti pelatihan tersebut karena pengetahuan peserta bertambah. Pemahaman mengenai pendidikan inklusi menjadi lebih luas, memahami perbedaan antara pendidikan khusus dan pendidikan inklusi, serta pemahaman mengenai macam-macam disabilitas secara lebih komprehensif. Bahkan satu peserta menyatakan bahwa "Pendidikan inklusi ini tidak hanya tentang kesetaraan, tetapi tentang "merayakan perbedaan' yang dimiliki oleh tiap individu” (Beutel et al., 20/8). Di Indonesia, kerjasama dalam lingkup internal masih perlu ditingkatkan karena di Indonesia sendiri sudah memiliki resource center yang berfokus untuk menyediakan pelayanan, peralatan, perlengkapan, dan sarana yang dibutuhkan 
bagi sekolah inklusi untuk dapat menyelenggarakan pendidikan inklusi di Indonesia. Di Jawa Timur sendiri, sudah ada Tim Pokja Pendidikan Inklusif Jawa Timur yang siap ketika diminta tolong untuk memberikan materi pelatihan kepada guru kelas mengenai pendidikan inklusi.

Konteks lainnya yang terjadi di Republik Ceko yaitu, negara harus memberikan pendidikan terhadap anak-anak pengungsi dari Myanmar. Terdapat beberapa kendala dalam pemberian pendidikan, diantaranya yaitu hambatan bahasa yang berbeda, dan kurang adanya pendidikan bahasa Ceko terhadap anak-anak pengungsi. Untuk mengatasi hambatan ini, strategi dilakukan dengan memberikan seminar CPD (Continuing Professional Development) yang disesuaikan konteks budaya anak-anak Myanmar selama satu hari penuh dan dilanjut dengan seminar selama tiga hari (Bačáková \& Closs, 20 I3). Terdapat hasil positif dari seminar ini, yaitu adanya perkembangan positif tentang sumber belajar yang tersedia untuk anak-anak pengungsi. Selain itu, guru juga terbiasa bekerjasama dengan pihak lain seperti organisasi non-pemerintah untuk berbagi pengalaman dan pengetahuan tentang penyelenggaraan pendidikan inklusi (Bačáková \& Closs, 20I3).

Untuk menciptakan hal ini, perlu penerimaan dari orangtua bahwa anaknya memiliki kekhususan tertentu dengan anak lainnya. Butuh komitmen untuk mencari solusi dari kekhususan yang dialami oleh anak, bukan malah menyembunyikan kekhususan yang dimiliki oleh anak terhadap dunia luar. Perlu penerimaan dari teman-teman di sekitar lingkungan anak, baik teman-teman di sekolah maupun teman-teman sepermainan bahwa temannya memiliki kondisi dan kebutuhan yang berbeda dengan teman-teman 'normal' lainnya.

Perlu kesadaran dari guru sekolah tentang pentingnya sekolah inklusi, dan pentingnya individu dengan disabilitas tetap bisa belajar bersama dengan teman normal lainnya di dalam satu kelas yang sama. Butuh komitmen bagi guru untuk siap menerima pengetahuan dan keterampilan yang dibutuhkan untuk menghadapi dan mengajar siswa dengan disabilitas, karena individu dengan disabilitas, terutama yang memiliki ketunaan, seperti tuna netra, tuna rungu, dan tuna wicara membutuhkan penanganan khusus dan instruksi khusus dari guru.

Perlu kesadaran dari kepala institusi untuk membuat kebijakan dan peraturan yang ramah terhadap siswa dengan disabilitas. Butuh komitmen untuk mau menerima siswa dengan disabilitas, bukan malah merasa keberatan dengan adanya siswa dengan disabilitas. Butuh komitmen untuk menyisihkan sekian persen dari perencanaan anggaran sekolah/ institusi untuk membuat fasilitas sekolah/ institusi yang dapat dijangkau dengan mudah oleh siswa dengan disabilitas. Butuh komitmen untuk membuat kurikulum yang disesuaikan dengan kebutuhan pendidikan anak dengan disabilitas, contohnya seperti pembuatan kurikulum IEP (Individualized Educational Program) atau PPI (Program Pembelajaran Individu) bagi siswa yang membutuhkan SEN (Special Education Needs).

Perlu kesadaran dari pemangku jabatan mengenai kebijakan yang dibuat untuk individu dengan disabilitas hendaknya dapat menjawab tantangan dan hambatan yang dialami oleh individu, tidak hanya kebijakan semata tanpa mengetahui realitas di lapangan. Perlu adanya sinkronisasi yang harmonis antara kondisi ideal yang tertulis pada kebijakan dengan realitas di lapangan, tentunya dengan bekerjasama dengan berbagai pihak yang terlibat dengan individu-individu dengan disabilitas dan stakeholders. Butuh komitmen untuk menyisihkan sekian persen dari anggaran dan pendapatan dan belanja daerah/ negara untuk dapat membangun dan menyediakan fasilitas umum yang ramah terhadap disabilitas

\section{Kesimpulan}

Sudah lebih dari satu dekade sejak kebijakan CRPD dikeluarkan oleh PBB yang tujuannya agar masyarakat menjadi lebih ramah terhadap disabilitas. Juga tidak ada sanksi yang akan diberikan jika kebijakan CRPD masih belum dilaksanakan sepenuhnya oleh negara. Namun masih saja ada hambatan yang dialami oleh beberapa negara dalam menyelenggarakan pendidikan inklusi, yaitu kurangnya pelatihan guru ( 9 penelitian), sikap negatif terhadap disabilitas ( 8 penelitian), pemahaman guru tentang disabilitas dan identifikasi disabilitas (7 penelitian), kurangnya pembedaan instruksi, hambatan dalam aksesibilitas (masing-masing 6 penelitian), kesalahan dalam pembuatan kebijakan, 
kebijakan institusional yang kurang memahami disabilitas, dan jumlah kelas yang besar (masingmasing 5 penelitian), kurangnya kesadaran masyarakat terhadap disabilitas, sumber daya yang terbatas (masing-masing 4 penelitian), keterbatasan finansial ( 3 penelitian), kurangnya kerjasama antar guru dan antar elemen masyarakat, kecemasan guru, dan permasalahan pada keterlibatan orangtua dalam pendidikan anak dengan disabilitas (masing-masing 2 penelitian), kondisi alam yang kurang bersahabat, dan kekhawatiran akan prestasi siswa dengan disabilitas (masing-masing I penelitian).

Berbagai usaha telah dilakukan oleh berbagai pihak untuk mengurangi kesenjangan antara kebijakan yang tertulis di atas kertas putih sebagai kondisi yang ideal dengan realitas yang terjadi di lapangan. Strategi yang sedang dan telah dilakukan oleh beberapa negara untuk mengatasi hambatan dan mengoptimalkan pendidikan inklusi yaitu dengan peningkatan kualitas in-service training (INSET) kepada guru pendidikan inklusi, awareness programmes, school-based professional development programmes, family support, kontekstualisasi proses belajar-mengajar, rencana implementasi kebijakan yang memberikan dukungan berkelanjutan selama proses implementasi di lapangan, komitmen dari pemerintah untuk memberikan sebagian prosentase dari Gross National Product (GNP) sebagai sumber dana pendidikan inklusi dalam rancangan budgeting nasional, pertemuan dengan stakeholders untuk memberikan informasi tentang keuntungan dari adanya pendidikan inklusi, kerjasama dan kolaborasi dengan stakeholders, dan kerjasama dan kolaborasi secara regional, nasional, maupun internasional.

Menciptakan lingkungan yang seperti itu tidak mudah, mengingat ada banyak sekali tantangan dan hambatan yang ditemukan di lapangan. Ada beberapa strategi yang dapat dilakukan di Indonesia, yaitu dengan melakukan pelatihan kepada guru kelas untuk dapat mengajar di kelas inklusi dan dapat menggunakan sumber belajar yang menunjang keberlangsungan pendidikan inklusi, menyelenggarakan awareness program contohnya seperti 'a day on a wheelchair', bekerjasama dengan tim Pokja yang memiliki resource center yang mendukung implementasi pendidikan inklusi, hingga keterlibatan pemerintah seperti penyediaan dana untuk menyelenggarakan pelatihan guru kelas, dan membangun fasilitas umum yang lebih ramah terhadap individu dengan disabilitas seperti bidang landai/ bidang miring, lift, guiding block, dan transportasi umum yang ramah terhadap individu dengan tuna daksa yang menggunakan kursi roda. Dengan kita melakukan strategi-strategi tersebut, kita turut berpartisipasi dalam penyelenggaraan pendidikan inklusi dan menciptakan sebuah dunia dimana individu dengan disabilitas tidak harus lagi menyembunyikan disabilitasnya tetapi ikut 'celebrating diversity' bersama dengan individu 'normal' lainnya.

\section{REFERENSI}

Abongdia, J. A., Foncha, J. W., \& Dakada, A. (20I5). Challenges encountered by teachers in identifying learners with learning barriers: Toward inclusive education. International Journal of Educational Sciences, 8(3), 493-50 I. Doi: I 0.1080/0975 I I 22.20 I 5.I I 89027 I

Ahsan, M. T., Sharma, U., \& Deppeler, J. M. (20I2). Challenges to prepare pre-service teachers for inclusive education in Bangladesh: Beliefs of higher educational institutional heads. Asia Pacific Journal of Education, 32(2), 24I-257. Doi: I0.1080/02 I 8879I.20I 2.655372

Bačáková, M., \& Closs, A. (20/3). Continuing professional development (CPD) as a means to reducing barriers to inclusive education: Research study of the education of refugee children in the Czech Republic. European Journal of Special Needs Education, 28(2), 203-216. Doi: I0.1080/08856257.2013.778108

Beutel, D., Tangen, D., \& Carrington, S. (2018). Building bridges between global concepts and local contexts: implications for inclusive education in Nepal, Sri Lanka, and Bangladesh. International Journal of Inclusive Education, 23(1), 109-124. Doi: $10.1080 / 13603116.2018 .15 \mid 4763$

Bhatnagar, N., \& Das, A. (20I4). Regular school teachers' concerns and perceived barriers to implement inclusive education in New Delhi, India. International Journal of Instruction, 7(2), 89- 
102.

Centre for Services and Information on Disability (CSID). (2002). Educating children in difficult circumstances: Children with disabilities. Dhaka: CSID.

Department of Education. (200I). Education White Paper 6: Special Needs Education: Building an Inclusive Education and Training. Pretoria: Government Printer.

EC (European Commission). (2010). "Final Communication from the Commission to the European Parliament, the Council, the European Economic and Social Committee and the Committee of the Regions European Disability Strategy 2010-2020: A Renewed Commitment to a Barrier-free Europe." (Patent No. 636). COM(2010).

Education for All Movement. (200I). Sarva Siksha Abhiyan. India: Education for All Movement.

Genova, A. (20I5). Barriers to inclusive education in Greece, Spain and Lithuania: results from emancipatory disability research. Disability \& Society, 30(7), 1042-1054. Doi: 10.1080/09687599.2015.1075867

Jia, L., \& Santi, M. (2020). Chinese regular classroom teachers' understanding of barriers to inclusive education. Italian Journal of Special Education for Inclusion, 8(I), 218-236. Doi: 10.7346/sipes-0I-2020-17

Kawser, U., Ahmed, M., \& Ahmed, M. (20I6). Barriers of Inclusive Education in Bangladesh: Making Inclusion a Reality. Journal of Social Sciences \& Humanities Research, 2(2), I-4.

Moher, D., Shamseer, L., Clarke, M., Ghersi, D., Liberati, A., Petticrew, M., Shekelle, P., Stewart, L. A., Estarli, M., Barrera, E. S. A., Martínez-Rodríguez, R., Baladia, E., Agüero, S. D., Camacho, S., Buhring, K., Herrero-López, A., Gil-González, D. M., Altman, D. G., Booth, A., ... Whitlock, E. (20I6). Preferred reporting items for systematic review and meta-analysis protocols (PRISMA-P) 2015 statement. Revista Espanola de Nutricion Humana y Dietetica, 20(2), I48-160. Doi: I0.I I86/2046-4053-4-I

PIFS (Pacific Islands Forum Secretariat). (2009). The Pacific Education Development Framework. Tonga:

PIFS. http://www.forumsec.org.fj/resources/uploads/attachments/\%0Adocuments/Pacific Education Development Framework 2009-20I5.pdf

Potgieter-Groot, L., Visser, M., \& Lubbe-De Beer, C. (20I2). Emotional and behavioural barriers to learning and development in the inclusive education classrooms in South Africa: Developing a training programme for teachers. Journal of Child and Adolescent Mental Health, 24(I), 59-7I. Doi: I0.2989/I7280583.20I I.639775

Sharma, U., Armstrong, A. C., Merumeru, L., \& Simi, J. (2018). Addressing barriers to implementing inclusive education in the Pacific. International Journal of Inclusive Education, 23(I), I-I4. Doi: 10.1080/I3603 I 16.2018.15 I475 I

Sharma, U., Loreman, T., \& Simi, J. (20I7). Stakeholder perspectives on barriers and facilitators of inclusive education in the Solomon Islands. Journal of Research in Special Educational Needs, I7(2), |43-15।. Doi: I0.1 II I/I47|-3802.12375

UNESCO. (1994). The Salamanca Statement and Framework for Action on Special Need Education. Salamanca, Spanyol: UNESCO.

United Nations. (2006). Convention Rights Persons with Disabilities. New York: United Nations.

World Bank. (2018). The World Bank in Pacific Islands. World Bank. http://www.worldbank.org/en/country/\%0Apacificislands/overview

Yatim, D. I. (20I5). Mempersiapkan Generasi Remaja Berencana (SERI GENRE - Buku 5). Jakarta: Badan Kependudukan dan Keluarga Berencana Nasional. 